https://helda.helsinki.fi

\title{
Leibniz and the Amour Pur Controversy
}

\author{
Roinila, Markku
}

2013-10-25

Roinila , M 2013 , ' Leibniz and the Amour Pur Controversy ' , Journal of Early Modern Studies , vol. 2 , no. 2 , pp. 35-55 . https://doi.org/10.7761/jems.2.2.35

http://hdl.handle.net/10138/192040

https://doi.org/10.7761/jems.2.2.35

cc_by_nc_nd

draft

Downloaded from Helda, University of Helsinki institutional repository.

This is an electronic reprint of the original article.

This reprint may differ from the original in pagination and typographic detail.

Please cite the original version. 


\title{
Leibniz and the Amour Pur Controversy
}

\author{
Markku Roinila \\ University of Helsinki
}

\begin{abstract}
The topic of disinterested love became fashionable in 1697 due to the famous amour pur dispute between Fénelon (1651-1715) and Bossuet (1627-1704). It soon attracted the attention of Electress Sophie of Hanover (1630-1714) and she asked for an opinion about the dispute from her trusted friend and correspondent, the Hanoverian councilor Gottfried Wilhelm Leibniz (1646-1716). This gave Leibniz an opportunity to present his views on the matter, which he had developed earlier in his career (for example, in Elementa juris naturalis of 1671 and Codex iuris gentium of 1693). In his 1697 letter to Sophie he did not explicitly take sides in the dispute, but formulated his own views on the topic in a theological manner, aiming to provide an account of disinterested love which would surpass the doctrines of both French theologians. In addition to presenting Leibniz' early views on disinterested love and examining this alternative formulation of his views on love, I will show that after the letter Leibniz gave this alternative perspective up and returned to his earlier, more philosophical views on the topic, which suggests that he regarded them to be superior to the theological version, where the virtue of charity was related to the virtue of hope.
\end{abstract}

Keywords: Leibniz, Electress Sophie of Hanover, pure love controversy, Fénelon, Bossuet, love, hope, charity.

\section{Introduction}

The topic of disinterested love became fashionable in 1697 due to the famous amour pur dispute between Fénelon (1651-1715) and Bossuet (16271704). It soon attracted the attention of Electress Sophie of Hanover (16301714) and she asked for an opinion about the dispute from her trusted friend and correspondent, the Hanoverian councilor Gottfried Wilhelm Leibniz (1646-1716). This was good news for Leibniz, as he not only had an interest 
in the dispute, but also had his own views on the topic. However, there is no evidence that she ever answered Leibniz' lengthy letter.

Although the discussion perhaps went no further, Leibniz letter is intriguing and deserves attention because it places his earlier views on disinterested love in the context of the heated theological controversy and shows how Leibniz applied his jurisprudential-ethical doctrine to a theological framework. His purpose seems to have been to persuade Sophie of the superiority of his doctrine compared to the views of the French theologians. The letter remains the only occasion when Leibniz was prepared to modify his doctrine of disinterested love, published in his 1693 Codex iuris gentium.

I will present Leibniz doctrine of disinterested love and discuss a few recent interpretations of its coherence, discuss the letter to Sophie and show how Leibniz modified his doctrine to place it in the context of the pure love controversy. I will also show that he returned to his earlier, more philosophical formulations of love after the letter to Sophie, arguing that the theologians participating in the controversy should have followed his doctrine, which offers an optimal solution to the central problem of our motivation concerning salvation.

\section{Disinterested Love: Egoism or Altruism?}

Leibniz' mature published writing on disinterested love is the Preface to the Codex iuris gentium (1693), which is a large collection of medieval documents supporting the position of the Holy German Roman Empire against French claims. ${ }^{\text {In the Preface Leibniz }}$ praises universal benevolence, which is the habit of loving or willing the good of another:

Love then signifies rejoicing in the happiness of another, or, what is the same thing, converting the happiness of another into one's own. With this is resolved a difficult question, of great moment in theology as well: in what way disinterested love is possible, independent of hope, of fear, and of regard for any question of utility. In truth, the happiness of those whose happiness pleases us turns into our own happiness, since things which please us are desired for their own sake. ${ }^{1}$

Disinterested or pure love is joy or pleasure in another person's well-being. According to Patrick Riley, there is a necessary connection between our practicing disinterested love and God's love for his creation, the best of all possible worlds. As God is the source of the actual world we live in, reflecting his perfections is the greatest and most durable pleasure there can be because

${ }^{1}$ Gottfried Wilhelm Leibniz, Political Writings, trans. and ed. with and introduction and notes by Patrick Riley, $2^{\text {nd }}$ edition, Cambridge: Cambridge University Press, 1988 (henceforth R), p. 171; Gottfried Wilhelm Leibniz, Die Werke, ed. by Onno Klopp, Hanover: Klindworth, 1864-84 (henceforth K), I, 6, p. 470. 
God represents infinity and the greatest perfection. Loving other people is a consequence of loving God as we are made in his image. Although many formulations of the doctrine of disinterested love are related to a long tradition of Christian thinkers (especially the Gospel of St. John), Leibniz discusses it in the context of justice, which he consistently defined as the charity of the wise (caritas sapientis). ${ }^{2}$

However, he argues that his doctrine can be used in a theological context, too: with it one can resolve the difficult question of love independently of hope and fear and any question of utility. Leibniz modifies Roman law to fit this idea by converting the highest degree of "live honestly" to "live piously" or charitably. ${ }^{3}$

In this way Leibniz' doctrine strives to reconcile the competing motivations of egoism and altruism. Wise and virtuous men act analogously to God, who loves his creation disinterestedly. In Méditation sur la notion commune de la justice (1702-1703?) Leibniz argues that God and men have essentially the same motivation to promote perfection and because of that, men's supreme function is to imitate divinity within the limits of human nature. ${ }^{4}$

The two apparently conflicting motivations of one's own good and the good of others are necessarily tied to each other. The fullest discussion of the motivational grounding of Leibniz' doctrine is found in his first substantial account of disinterested love, an unpublished memoir titled Elementa juris naturalis (1670-1671); I will refer here to the most complete version of it, $12_{4}$ (A VI, 1, pp. 459-465). Leibniz argues that "the sciences of the just and the useful, that is, of the public good and of their own private good, are mutually tied up in each other." ${ }^{5}$ However, the right reason for our actions is identified with prudence. He says:

Prudence $[\ldots]$ cannot be separated from our own good, and any statement which contradicts this is empty and foreign to the actual practice of those who utter it, whatever they may say against it. There is no one who deliberately does anything except for the sake of his own good, for we seek the good also of those whom we love for the sake of the pleasure which we ourselves get from their happiness. ${ }^{6}$

${ }^{2}$ Patrick Riley, Leibniz' Universal Jurisprudence: Justice as the Charity of the Wise, Cambridge, MA: Harvard University Press, 1996, pp. 141-144.

${ }^{3}$ Ibid., p. 199.

${ }^{4}$ Gottfried Wilhelm Leibniz, Rechtsphilosophisches aus Leibnizens Ungedruckten Schriften, ed. by Georg Mollat, Leipzig: Robolsky, 1885 (henceforth M), p. 72.

${ }^{5}$ Gottfried Wilhelm Leibniz, Philosophical Papers and Letters, trans. and ed. with an introduction by Leroy E. Loemker, $2^{\text {nd }}$ edition, Dordrecht: Reidel, 1976 (henceforth L), p. 132; Gottfried Wilhelm Leibniz, Sämtliche Schriften und Briefe, Berlin: Akademie, 1923(henceforth A), VI, 1, p. 460.

${ }^{6}$ L, p. 134; A VI, 1, p. 461. 
Here Leibniz states quite clearly that the primary motivation is our own good, and our motivation to wish for the happiness of other people is to gain pleasure from their happiness. Therefore there seems to be only one motivation, prudence. This view is problematic, however: if our primary motive would be a reward for helping others, we would not care to do that if no reward is promised. ${ }^{7}$ Because of this Leibniz provides a new way of understanding how to reconcile egoistic and altruistic motivations:

There is a twofold reason for desiring the good of others; one is for our own good, the other as if for our own good. The former is calculating, the latter loving. The former is the affection of a master for his servant, the latter that of a father for his son $[\ldots]$ the former for the sake of some other expected good, the latter for its own sake. But, you ask, how is it possible that the good of others should be the same as our own and yet sought for its own sake? For otherwise the good of others can be our own good only as means, not as end. I reply on the contrary that it is also an end, something sought for its own sake, when it is pleasant. ${ }^{8}$

Leibniz is saying here that that which is pleasant is sought for its own sake and that there are two reasons to help others, of which one is directly for our own good (the calculating motivation) and another indirectly for our own good, which is properly love (the altruistic motivation).

In a recent paper Noa Naaman Zauderer has suggested that we can act on both motivations at the same time. The pleasure sought for its own sake is greater than the one that is sought for mercenary or calculating motives, as another's pleasure increases or builds upon our own pleasure. The pleasure of the other is expressed or mirrored and in this way it intensifies our own pleasure. According to Naaman Zauderer, we can have both the objective of helping others and our own good simultaneously in mind as ends. If our motivation is mercenary, the pleasure gained is smaller than from what follows from acting according to disinterested motivation. Thus one must take the other's welfare to be also a means for one's own benefit, bringing together the two motivations. However, if a just man acts on both these motivations, one is likely to be the consequence of the other, and one is not necessarily aware of both motivations at the same time. Thus Naaman Zauderer interprets the phrase as if in the passage as referring to non-conscious motivation, arguing that while we may consciously desire to benefit others, our underlying unconscious motive may be egoistic. ${ }^{9}$

${ }^{7}$ A VI, 1, pp. 462-463.

${ }^{8}$ L, p. 136; A VI, 1, p. 463.

9 Noa Naaman-Zauderer, "Rethinking Leibniz' Notions of Justice, Love and Human Motives," in Herbert Breger, Jürgen Herbst und Sven Erdner (eds.), Einheit in der Vielheit. VIII. Internationaler Leibniz-Kongress, Vorträge 2, Hannover: Gottfried-WilhelmGeschellschaft, 2006, pp. 671-676, at pp. 672-674. 
This is a fresh approach, but it faces the difficulty that Leibniz does not mention unconscious motivations. He seemingly first wrote on unconscious perceptions in his Meditationes de cognitatione, veritate et ideis in 1684, over ten years after the Elementa. Therefore it seems to me that with respect to Leibniz' original doctrine of disinterested love in the Elementa, there are only conscious, known motivations. ${ }^{10}$

In response to Naaman Zauderer, Gregory Brown presents a novel interpretation of the key passage above. According to Brown, there is only one motivation, namely our pleasure. The principal reason for the confusion in Leibniz scholarship concerning Leibniz views is the widely used translation by Loemker, which in this passage is seriously misleading. As Brown persuasively shows, the passage should be interpreted to mean that to desire the good of others propter nostrum bonum (for the sake of our own good) is to desire it, not as an immediate source of pleasure in itself, but rather as a means of obtaining something else that is an immediate source of pleasure. ${ }^{11}$ Thus, if I help a woman in trouble propter nostrum bonum, my pleasure does not come directly from her happiness, but indirectly from somewhere else, such as a reward I hope to receive. I do not really love her, but my own good. Therefore, the pleasure is not gained as a direct consequence of helping another person.

On the other hand, if we desire something quasi nostrum bonum (as if it were our own good), this is to desire it because it is an immediate source of our pleasure, i.e., because we find our pleasure immediately in the perception of this good (without any reward). In this case our desire for our own good is what moves us to desire the good of those whom we love. The other is not a means as in the first case, but an end, and this is properly disinterested love. In other words, we find ourselves pleased to desire the good of the loved one. Accordingly, while in the first case the good is a consequence of our good deed, in the latter case the good of those whom we love disinterestedly is constitutive of our own good and there is no conflict between the two motives. ${ }^{12}$

${ }^{10}$ There is no mention of unconscious motivations in the 1693 Codex either. Also, in Nouveaux essais sur l'entendement humain (NE, 1704) Leibniz does not say a word about unconscious motivations in the relevant passage of II, $\mathrm{xx}, \S 6$, despite the fact that in the next paragraph he goes on to discuss disquiet, which is constituted by minute, insensible perceptions. In addition, he argues in II, xxi, $\S 5$ that we are always aware of our volitions. A decision to help the other person is clearly founded on a volition, although in the same work Leibniz also discusses the instinct of sociability (NE I, ii, §9). This instinct in itself, however, is only an appetition which inclines us towards other people. A genuine volition to help others requires conscious actions.

${ }^{11}$ Gregory Brown, “Disinterested Love: Understanding Leibniz' Reconciliation of Self- and Other-Regarding Motives," British Journal for the History of Philosophy 19 (2011), pp. 265-303, at pp. 274-275.

${ }^{12}$ Gregory Brown, “Leibniz' Moral Philosophy,” in Brandon C. Look (ed.), Continuum Companion to Leibniz, London: Continuum, 2011, pp. 228 and 230; Brown, "Disinterested Love," p. 277. 
The noteworthy thing about Brown's interpretation is that, whereas Leibniz' account has been usually seen as reconciling egoistic and altruistic motivations, in his account both cases are based on our egoistic motivations. Thus there are not two ends we strive for at the same time, but only one end, our pleasure. Brown admits that if one defines altruistic actions as those that are motivated by a desire for the good of others without any concern for the agent's own good, Leibniz' theory simply does not accommodate this motivation. ${ }^{13}$ Judging by the Elementa, this actually seems to be the case-Leibniz is explicit that we cannot escape our prudential motivation. However, when our striving is put to good use, that is, to promoting the good of others, it is virtuous. To my mind, Brown's approach and his interpretation of the key passage presented above is the most accurate account available. My subsequent examination of Leibniz' letter to Sophie is also in line with it.

Bearing this in mind, we can turn to the details of how another's wellbeing affects us. According to Naaman Zauderer, pleasure is multiplied, intensifying or adding to our own pleasure when we love the other disinterestedly. She argues that Leibniz' statement that finding pleasure in another person's well-being does not rule out the possibility that we also find a certain amount of pleasure when we seek our own good. ${ }^{14}$ Following Brown, we can say that the pleasure following from mercenary motivation comes from my own good, not from the good of the other. So it has another source than the immediate pleasure following from disinterested love. In the Codex Leibniz argues that by loving the other disinterestedly, that person's happiness is converted to our happiness. ${ }^{15}$ There is no mention of increase of pleasure-rather, Leibniz seems to be saying that the other's happiness produces our happiness. This would suggest that the other's pleasure is different in kind to our own pleasure, as it has to be converted. This would seem to be a counter-argument to Naaman Zauderer's interpretation that there can be two motivations (founded on pleasure) present in the mind at the same time. However, Leibniz does seem to argue for the doubling of pleasure in the Elementa:

Pleasure, however, is doubled by reflection, whenever we contemplate the beauty within ourselves which our conscience makes, not to speak of our virtue $[\ldots]$ For every mind is something like a mirror, and one mirror is in our mind, another in the mind of someone else. So if there are many mirrors, that is, many minds recognizing our good, there will be a greater light, the mirrors blending the light not only in the eye but also among each other. The gathered splendour constitutes glory. ${ }^{16}$

${ }^{13}$ According to Brown, Leibniz was committed to some form of psychological egoism, perhaps a form of mitigated egoism: Brown, "Disinterested Love," pp. 266 and 282-285.

${ }^{14}$ Noa Naaman-Zauderer, "Rethinking Leibniz' Notions of Justice, Love and Human Motives," p. 672.

${ }^{15} \mathrm{~K}, \mathrm{I}, 6, \mathrm{p} .470$.

${ }^{16}$ L, p. 137; A VI, 1, p. 464. 
To my mind, in this passage Leibniz is arguing that pleasure is multiplied in us when we reflect our virtue and its cause is our own goodness. The more other minds recognize our perfection, the greater the increase of general perfection and beauty in the world. This recognition, however, is founded on immediate pleasure which follows from disinterested love-a little earlier Leibniz defined beauty as contemplation of that which is pleasant. ${ }^{17}$ In Nouveaux essais Leibniz argues that joy is a state where (intellectual) pleasure predominates over displeasure in us. ${ }^{18}$ The two kinds of pleasure from different motivations cannot be combined and Leibniz is clear in recommending the pleasure derived from perfection rather than the pleasure derived from the senses. ${ }^{19}$ In the Elementa Leibniz in fact argues that the good of others may sometimes require us to suffer: "Justice will be the habit of deriving pleasure from an expectation of the good of others, even to the expectation of our own pain." ${ }^{20}$

Happiness is a process which requires a continuous state of virtue and wisdom, giving us a readiness to feel joy from perceiving perfection. ${ }^{21}$ This must be what Leibniz refers to in the Elementa when he is discussing beauty within ourselves. In the Codex Leibniz expresses the same ideal as follows: "By moral I mean that which is equivalent to 'natural' for a good man [...] a good man is one who loves everybody, in so far as reason permits." 22

It is not clear what this "natural" is, but it seems to me that he is thinking of man as a created being and therefore the virtue or beauty of man is founded on our innate dispositions (for example, pleasure as striving for perfection). ${ }^{23}$ Another passage in the Codex would seem to support this: "Since God possesses supreme power and supreme wisdom, his happiness does not simply become ours (if we are wise, that is, if we love him), but even creates ours." ${ }^{24}$ Love of created beings can give us some pleasure, but God alone can create all our happiness. ${ }^{25}$

Brown argues along similar lines, saying that perfection of the mind is constitutive of the happiness of persons. However, he does not discuss innate

${ }^{17}$ Ibid.

${ }^{18} \mathrm{NE}$ II, xx, §7; A VI, 6, p. 166.

${ }^{19}$ See, for example, La Félicité, in Gottfried Wilhelm Leibniz, Textes Inédits d'après les manuscrits de la Bibliothèque provinciale de Hanovre, publiés et annotés par Gaston Grua, Paris: Presses Universitaires de France, 1948 (henceforth G), p. 579. See also Principles of Nature and Grace, §16, in Gottfried Wilhelm Leibniz, Die philosophischen Schriften, ed. by G. I. Gerhardt, Hildesheim: Olms, 1961 (henceforth GP), VI, p. 605.

${ }^{20}$ L, p. 137; A VI, 1, p. 465.

${ }^{21}$ See Leibniz' letter to Ernst August, A I, 4, p. 315.

${ }^{22}$ R, p. 171; K, I, 6, pp. 469-470.

${ }^{23}$ Beauty of a person is discussed in more detail in a letter to Arnauld in 1671 where Leibniz defined it as an optimum between wisdom and power. A II, I, p. 174. Of innate dispositions, see NE, Preface, A VI, 6, pp. 48-52.

${ }^{24}$ R, p. 171; K, I, 6, p. 470.

${ }^{25}$ Leibniz to Nicaise, GP II, p. 578. 
dispositions, saying only that the perfections of God are transferred to happy persons. To my mind, however, Leibniz can be interpreted as saying that because we have an inner disposition towards God, we strive to imitate him and when we succeed in this task, we perceive perfection. This happens when we practice disinterested love. ${ }^{26}$ In other words, disinterested love is related to action, as pleasure is an appetite towards perfection. ${ }^{27}$ Another way of understanding "natural" is to see it as prudential moral philosophy where we strive to be charitable to others, but do not ignore our own interests. Thus it is simply practicing disinterested love as Leibniz defines it in the Elementa juris naturalis. ${ }^{28}$

Finally, I will briefly discuss an opposite case of our pleasure which Brown does not mention. Leibniz wrote to Arnauld in 1671 that the unhappiness of others produces pain in us. ${ }^{29} \mathrm{I}$ think this shows that Leibniz' doctrine works the other way around, too. Unhappiness found in the loved one introduces an immediate displeasure in us, reflecting universal imperfection. It would seem (in the interpretation I have supported) that if our motivation to love the other were mercenary, the unhappiness of the other would not really affect us, as our source of pleasure would come from somewhere else. Thus it is only the unhappiness of those we love disinterestedly that produces pain in us. It seems to me to be clear, however, that mercenary motives will eventually bring us indirect pain as the pleasure following from self-interested motivation is temporary and can introduce a greater pain, unlike disinterested love, which produces a lasting pleasure.

We have seen that Leibniz' doctrine of disinterested love had an early origin in his writings and reached maturity in his 1693 publication Codex iuris gentium. While the doctrine of disinterested love is related to a long tradition of Christian writers, Leibniz usually discusses the doctrine in a philosophical or jurisprudential rather than a theological context. His premise in the Codex about the suitability of the doctrine to theological problems was put to the test in the late 1690s.

${ }^{26}$ Brown, "Disinterested Love," pp. 292-303.

${ }^{27}$ NE II, xxi, §72; A VI, 6, p. 210.

${ }^{28}$ This reading is presented in Ursula Goldenbaum, "It's Love! Leibniz's Foundation of Natural Law as the Outcome of His Struggle with Hobbes' and Spinoza's Naturalism," in Mark Kulstad, Mogens Lærke and David Snyder (eds.), The Philosophy of the Young Leibniz, Stuttgart: Steiner, 2009, pp. 189-201. However, I disagree with Goldenbaum (p. 196) on the point that the natural moral philosophy promoted by Hobbes would in Leibniz' case rule out any kind of innate principle of sociability. He clearly maintains this in Nouveaux essais I, ii, 9 (A VI, 6, 93). For Leibniz, both prudence and instinct for affection towards the members of our own species lead us to disinterested love.

${ }^{29}$ A VI, 1, p. 280. 


\section{The Controversy of Pure Love}

The so-called amour pur controversy emerged in France in 1697 between two famous clerics and royal tutors, François Fénelon and Jacques-Bénigne Bossuet. ${ }^{30}$ The controversy was the result of different reactions to the views of the famous mystic and proponent of quietism, Mme Guyon (1648-1717). Her views were creating doubts in the court, especially in the mind of the unofficial wife of Louis XIV, Mme de Maintenon, and Bossuet was a member of a committee which officially condemned her views in $1695 .{ }^{31}$ In the background there was also Nicolas Malebranche's (1638-1715) analysis of love, especially in Traité de morale (1684). ${ }^{32}$

Fascinated by Mme Guyon's ideas, ${ }^{33}$ Fénelon published his book Explication des maximes des saints sur la vie intérieure in January 1697, where he argued that true love of God (charity) must be disinterested or completely free of self-interest even in the sense that the soul does not care about its own salvation. In perfect love of God one would lose oneself completely and desire nothing for its own sake except that God's will be done. This state of pure love is thus one of indifference with respect to salvation. In contrast, concupiscent love is subject to fear and hope (concerning life after death), which would be mercenary motives: the concupiscent lover himself, rather than God, is the ultimate end of this love. ${ }^{34}$

Bossuet answered his former protégés views six weeks later in his Instructions sur les états d'oraison, in which he argued that the true love of God was

${ }^{30}$ For a detailed account of the controversy, see Gabriel Joppin, Fénelon et la mystique du pur amour, Paris: Beauchesne, 1938.

${ }^{31}$ On Mme Guyon and pure love, see Nancy C. James, The Conflict over the Heresy of "Pure Love" in Seventeenth-Century France: The Tumult over the Mysticism of Madame Guyon, Lewinston: Mellen, 2008.

${ }^{32}$ Malebranche defines virtue as a dominant and stable habit of loving all there is in accordance with God's order. Loving is motivated by either light of the mind or by pleasure and our task as moral agents is to make loving God's order habitual. In this way we become one with God. Of special interest in the Treatise is chap. 8, sec. XV, which Malebranche added to the work in 1697 in order to distance himself from quietism, to which he was often associated. There he says: "Take away from the mind all self-love, all desire to be happy and perfect; let nothing be pleasing to it, the perfections no longer affecting it, and here doubtless you will have a person incapable of any love. If nothing can be pleasing to a person, how can he be pleased with God?" (Nicolas Malebranche, Treatise on Ethics (1684), trans. with an introduction by Craig Walton, Dordrecht: Kluwer, 1992, pp. 10-11, 105.) In 1699 he publicly rejected the claim by François Lamy that the Traité de morale supports the quietist position. See Tad Schmaltz, "Nicolas Malebranche," in Edward N. Zalta (ed.), The Stanford Encyclopedia of Philosophy (Winter 2009 Edition), [accessed on 23 July 2013] http://plato.stanford.edu/archives/win2009/entries/malebranche/.

${ }^{33}$ For the correspondence between Fénelon and Mme de Guyon, see Pierre-Maurice Masson, Fénelon \& Mme Guyon: documents nouveaux et inédits, Paris: Hachette, 1907.

${ }^{34}$ Robert Merrihew Adams, "Pure Love," Journal of Religious Studies 8 (1980), pp. 83-99, at pp. 83-85. 
and could only be motivated by one's desire for personal happiness. ${ }^{35}$ One is always motivated by one's own salvation and therefore the pure love of God is not indifferent. ${ }^{36}$ Desiring an eternal happiness and hoping for beatitude signifies in fact being in union with God-it is not obeying a selfish or egoistic law; it is acting in a way which corresponds to the way God has created us. Pure love is thus adoration of God which brings with itself a reward. Bossuet saw Fénelon's doctrine of pure love as the defiance of rational, logical Christianity. ${ }^{37}$ Fénelon, on the other hand, saw pure love as a perfection which is not open to all. It is through God's grace that one can progressively achieve that desired mystic union, and no intervention, expect His, is possible. ${ }^{38}$

The debate became increasingly heated and led to a war of letters and pamphlets before it was finally stopped by the condemnation of Fénelon's book by Pope Innocentius XII on $12^{\text {th }}$ of March $1699 .{ }^{39}$ Bossuet emerged as a winner in the three-year battle and Fénelon had to retire from court to the Archbishopric of Cambrai.

It is noteworthy that the controversy was of special interest to several learned women of the time. Most importantly, Madame Guyon was the instigator of the debate and the principal exponent of the quietist or semi-quietist cause in late seventeenth-century France. She argued that one can reach perfection internally within a short time by means of prayer and therefore the self should be suppressed, letting the Almighty take presence in us. Her views were criticized by many, especially Bossuet, as imaginary and mystical. ${ }^{40}$

In England, Mary Astell (1666-1731) was of a similar opinion to Madame Guyon and discussed the topic with the Platonist John Norris (1657-1711) in eleven long letters. Their correspondence was published in London in 1695 under the title Letters Concerning the Love of God, before the controversy in France broke out. Astell's approach to visionary metaphysics was attacked by yet another learned woman of the time, Damaris Masham (1658-1708), a close friend of John Locke's and later a correspondent of Leibniz'. She regarded Astell's views as religious enthusiasm and published a more empirically-minded

${ }^{35}$ Gottfried Wilhelm Leibniz, Leibniz and the Two Sophies: The Philosophical Correspondence, ed. and trans. by Lloyd Strickland, Toronto: Iter, 2011 (henceforth LTS), p. 174.

${ }^{36}$ According to Bossuet, this kind of indifference would exclude not only the hope of salvation, but also fear of justified punishment, which would subvert Christianity. See Patrick Riley, Leibniz' Universal Jurisprudence, p. 142.

${ }^{37}$ James Herbert Davis, Fénelon, Boston: Twayne, 1979, p. 86. For details concerning hope in the controversy, see Gabriel Joppin, Fénelon et la mystique du pur amour, chaps. 2-3. Bossuet's view is close to Malebranche's view of 1697, see footnote 31.

${ }^{38}$ Davis, Fénelon, p. 84.

${ }^{39}$ LTS, p. 174.

${ }^{40}$ Dániel Schmal, "The Problem of Conscience and Order in the Amour-Pur Debate," in Gábor Boros, Herman De Dijn, Martin Moors (eds.), The Concept of Love in Seventeenth and Eighteenth Century Philosophy, Leuven: Leuven University Press, 2008, pp. 113-124, at pp. 116-117. 
defense of the love of creatures and natural sociability (A Discourse Concerning the Love of God, 1696). ${ }^{41}$

\section{Leibniz' Response to the Controversy: The 1697 Letter to Electress Sophie}

The amour pur controversy had stirred widespread interest and Electress Sophie of Hanover, Leibniz' closest mentor, had heard of it as she was interested in theological matters. No known letter where Sophie asks Leibniz' opinion on the controversy or its topic exists, but Leibniz' letter to Sophie, probably written in the autumn of 1697 , clearly indicates that he had received such a request either by letter or in person.

Leibniz first became aware of the debates on disinterested love in mid-May 1697 when his correspondent, the Scottish cleric and scientist Thomas Burnett of Kemney (1654 -1729), mentioned to him the debate between John Norris and the then only 20-year-old Mary Astell. ${ }^{42}$ Soon Leibniz found out about the French controversy and he was happy to comment on it with Sophie.

Leibniz started the letter to the Electress by saying that he had read two or three documents about the dispute between the two renowned prelates of France, but he prefers to leave the solution of the controversy to the Pope. ${ }^{43} \mathrm{He}$ settles for giving his opinion on the matter and trusting it to Sophie's judgment:

I will only give here the ideas that I have had before on this subject, some of which have not been displeasing to Your Electoral Highness. Of all the matters of Theology there are none about which ladies have more right to judge than this one, because it concerns the nature of love. Although to form a judgment it is not necessary that they possess the great insights of Your Electoral Highness, whose penetration goes almost beyond that of most profound authors, I would also not want them to be as Madam Guyon is depicted, that is, ignorant devotees. I would want them to resemble Miss de Scudéry, who has clarified the characters and the passions very well in her

${ }^{41}$ Catherine Wilson, "Love of God and Love of Creatures: The Masham-Astell Exchange," in Gábor Boros, Herman De Dijn, Martin Moors (eds.), The Concept of Love in Seventeenth and Eighteenth Century Philosophy, Leuven: Leuven University Press, 2008, pp. 141-162, at p. 125. For another account of the correspondence concerning love between Astell and Norris, see Jacqueline Broad, Women Philosophers of the Seventeenth Century, Cambridge: Cambridge University Press, 2003, pp. 100-103, and for Masham's criticism, pp. 119-122. The supporters of religious enthusiasm argued that inspired and involuntary human activity directed by divine powers is to be preferred over our deliberate and willful conduct. On enthusiasm, see Michael Losonsky, Enlightenment and Action from Descartes to Kant: Passionate Thought, Cambridge: Cambridge University Press, 2001, chap. 5.

${ }^{42}$ GP III, p. 199.

${ }^{43}$ LTS, p. 175. According to Strickland, Leibniz probably did not read the two books by Fénelon and Bossuet, but instead some responses to them or reviews of the books. LTS, p. 175, n. 293. 
novels and in her Conversations about Morals, or at least like the English Lady Miss Norris, of whom it has been said that she has recently written so well on disinterested love. ${ }^{44}$

From the context it is clear that by giving his opinion on disinterested love Leibniz hopes for the Electress' response because he values her judgment. The beginning of the citation above suggests, furthermore, that the two had discussed the topic of love before. The discussion prompted by Leibniz' letter might have taken place sometime in the autumn of 1697 , but no known written evidence of such a discussion exists. ${ }^{45}$ To extend the persuasive character of the letter he also provides a list of well-known learned women who have succeeded in voicing their opinions in a reasonable form in contrast to Madam Guyon, who was known as a quietist and a mystic. Leibniz was consistently opposed to quietism, which stressed the need to go beyond suspending judgment-one was to empty one's mind and await directions from God on all matters. ${ }^{46}$

Leibniz starts his letter by reflecting on the theme of the controversy, that is, the love of God. He starts by saying that "to love is to find pleasure in the perfection or advantages of others and especially in their happiness." ${ }^{7} \mathrm{He}$ mentions beautiful things and intelligent substances, of which Sophie is a prime example. This (disinterested) love is so strong that all other pleasures come second and this concerns especially God whose perfections are supreme.

${ }^{44}$ LTS, pp. 175-176; A I, 14, pp. 54-55; note that Leibniz confuses Mary Astell with John Norris, whom he incorrectly refers to as "Miss Norris."

${ }^{45}$ See A I, 14, p. 54. Strickland argues that Leibniz could not have written the letter earlier than mid-May 1697 when he became aware of the controversy and it could not have been written later than in the spring of 1699 when the controversy ended. He also gives more reasons to date the letter to the autumn of 1697 (LTS, p. 174, n. 292). The Academy editors suppose that Leibniz sent the letter in mid-August 1697 because Sophie's daughter, soon-to-be Queen of Prussia, Sophie Charlotte, was visiting Hanover at the time and Leibniz must have thought that she would also see the letter. According to Utermöhlen, however, the letter was in fact based on discussions with both Sophie and Sophie Charlotte in Hanover: Gerda Utermöhlen, "Die Rolle fürstlicher Frauen im Leben und Wirken von Leibniz," in Hans Poser \& Albert Heinekamp (eds.), Leibniz in Berlin, Stuttgart: Steiner, 1990, pp. 44-60, at p. 51. As the correspondence between Leibniz and Sophie Charlotte started in late 1697 and grew more frequent in 1698-1699, I am persuaded by Strickland and Utermöhlen that the letter was written in the autumn of 1697 . However, no conclusive evidence on this exists.

${ }^{46}$ Richard Popkin, "The Religious Background of Seventeenth-Century Philosophy," in Daniel Garber and Michael Ayers (eds.), Cambridge History of Seventeenth-Century Philosophy, Cambridge: Cambridge University Press, 2003, pp. 393-422, at p. 403. The following criticism of quietism by Leibniz in Discours de Métaphysique, $\$ 4$ (1686) can well be extended to Fénelon's views: "we must not be quietists and stand ridiculously with arms folded, awaiting that which God will do [...] we must act in accordance with what we presume to be the will of God, insofar as we can judge it, trying with all our might to contribute to the general good [...]." A VI, 4, pp. 1535-1536; L, p. 305.

${ }^{47}$ LTS, p. 176; A I, 14, p. 55. 
Contemplating God's perfections is loving him and therefore love of God is necessarily related to our own good. As in the Elementa, Leibniz argues that one can enjoy divine love even if one believes that one is bound to be deprived of every other pleasure and even if one believes that one is about to suffer great pains. ${ }^{48}$

Although this may incline one to think that Leibniz is agreeing with Fénelon's opinion that we can love God without any other rewards, he allows only reasonable harm to oneself:

But to suppose that one continues to love God above all things and is nevertheless in eternal torments is to suppose something that will never happen. If someone were to make this supposition, he would be in error, and he would make it clear that he does not have sufficient knowledge of God's goodness, and consequently that he does not yet love him enough. ${ }^{49}$

Leibniz seems to have regarded Fénelon's position as a kind of mistrust of God's benevolence and contrary to our natural sense of prudence. In itself, this is not surprising, given that he was critical of Descartes' and Hobbes' voluntarism, arguing that one has to take into account not only God's power, but also his goodness and wisdom. ${ }^{50}$ Surely God with his supreme goodness would not want us to suffer terribly, especially as we love him disinterestedly? Thus it is evident that Leibniz preferred Bossuet's views in the controversy. Referring to Fénelon's book, he continues:

The Saints who doubtless would have agreed that God will not damn one who loves him above all things, and who have nevertheless said that they would love God even if they should have to be damned, intended to mean, by this false supposition, that the motives of the love arising from benevolence, or from the virtue of charity, are entirely different from the motives of the virtue of hope or the love arising from greed (which does not properly deserve the name of love). ${ }^{51}$

Like Fénelon, Leibniz distinguishes between the virtue of charity and the virtue of hope, associating the former with benevolent or disinterested love and the latter with mercenary love, a kind of theological version of prudence. The distinction itself, as Leibniz notes, derives from scholasticism ('amour bienveuillance vs. l'amour de cupidité). ${ }^{52}$ Unlike in his earlier writings on love, Leibniz presents the concupiscent or mercenary love, that is, the virtue of hope, in a favorable light even though

${ }^{48}$ LTS, pp. 176-177; A I, 14, p. 55.

${ }^{49}$ LTS, p. 177; A I, 14, p. 56.

${ }^{50}$ See M, p. 58.

${ }^{51}$ LTS, p. 177, A I, 14, p. 56.

${ }^{52}$ A I, 14, p. 56. 
he also argues that it does really deserve the name of love. He says that while disinterested love only consists in the pleasure which derives from the sight of the perfection and happiness of the object loved without considering any other good or profit which we can get from it, self-interested love is permitted, as it consists in the sight of our own good, without consideration for the happiness and advantage of others. ${ }^{53}$ Leibniz formulation is similar to the one found in Elementa and Codex with the exception that there he never said that calculating love is permissible-instead, he argued that it is unjust not to be delighted in the good of others when occasion arises. ${ }^{54}$

Leibniz argues that nothing prevents the actions of the two virtues, of charity and hope, from being exercised jointly. This is because one does not have to make a difference between willing God's goodness for oneself or for others. ${ }^{55}$ Thus, if I exercise the virtue of hope together with the virtue of charity, I hope for salvation not only for myself, but for all men. This is a different case from wanting it for only myself as would be the case in concupiscent love. Thus, Leibniz presents a theological version of his doctrine of love which is different from both Fénelon's and Bossuet's. While he could not accept the indifference of Fénelon, his view is also different from Bossuet's position, where the true love of God can only be motivated by one's desire for personal happiness.

Leibniz goes on to say that there is a "grand reflexion" of one of these virtues to another. When we are not content with our present love, we ask God for a greater knowledge (connoissance) in order to have more love and thus exercise an act of hope where our own good is the primary motivation. But when the pleasure we feel arises from God's perfections and makes us wish that this better understanding of God is common to all His creatures, we are exercising an act of benevolence. Leibniz argues that a sign of disinterested love towards God is to be content with his creation and to submit to his presumptive will, trusting that our future will be to our own good. ${ }^{56}$

One can see here an anticipation of the views in Essais de theodicée (1710). Trusting in God's wisdom and goodness will assure us that everything happens for our own good and this benevolent or disinterested love towards our creator will secure our good for us. Leibniz seems to be saying that when the virtue of hope is combined with the virtue of charity, we can hope for an increase in perfection with regard to the whole world. Thus, the virtue of charity in a sense includes the virtue of hope, but not the other way around. Leibniz argues that one of the strongest indications of a love of God which is sincere and disinterested is being satisfied with what one has already done, in the assurance that it is always the best, but also in trying to promote the common

\footnotetext{
${ }^{53}$ Ibid.

${ }^{54}$ A VI, 1, p. 465; K, I, 6, p. 470.

${ }^{55}$ A I, 14, p. 57.

${ }^{56}$ Ibid.
} 
good as found in God's known will in the past. ${ }^{57}$ Thus, the virtue of hope can be extended to our virtuous actions - our hope for a happy future requires us to practice charity or to love the other disinterestedly. Instead of waiting for the judgment day, we should strive to promote perfection in this world.

We have seen that Leibniz' account of love in his letter is different from his earlier writings. ${ }^{58}$ Unlike in the Codex, he argues that hope and disinterested love are related to each other instead of the latter being independent of the former. However, it is clear that although Leibniz says that self-interested love can be permitted, he does not allow it without a connection to charity or benevolence. It seems that Leibniz is in fact trying to persuade Sophie that charity is to be preferred by showing how hope for our own good can be understood within the context of practicing benevolence. Thus his account of love in the letter is especially tailored for Sophie as a preferable alternative to the solutions provided by Fénelon or Bossuet. His effort to combine both virtues is characteristic in the sense that he often tried to reconcile different opinions in order to find a solution which would be acceptable to all parties.

In the second part of the letter, Leibniz offers his previous, more philosophical views. He writes: "I wanted to go further into this matter some years ago, before it became stirred up in France." ${ }^{59} \mathrm{He}$ argues that with the help of the definitions given in the Codex one can find a non-mercenary type of love which is detached from hope and from fear and from all self-interested concerns. ${ }^{60}$ Leibniz seems to be saying that thanks to his philosophical doctrine of disinterested love the difficult topic of hope of salvation and fear of punishment can be avoided altogether. As disinterested love is an affect, a feeling based on pleasure, it does not require willing, which is essentially related to the Christian virtues. The main difference between hope as affect and hope as virtue seems to be that the affect includes its own reward, whereas the virtue of hope requires divine justice.

One may wonder what is the relationship between the first and the second part of the letter. If Leibniz is ready to modify, i.e., to theologize, his doctrine in the first part, why does he come back to his previous, philosophical views at all in the second? It seems to me that by giving both a theological and philosophical account of love he is trying to argue that his previous account can be applied to the theological context, and the outcome of both accounts suggests that benevolent or disinterested love is the only true form of love. One can interpret Leibniz' effort to explain benevolent love as including the Christian virtue of hope as an introduction to his earlier views, where the detachment

${ }^{57}$ A I, 14, p. 57.

${ }^{58}$ This seems to have escaped the attention of other commentators of Leibniz' doctrine. For example, Riley in his account of the pure love controversy comments only on the latter half of Leibniz' letter to Sophie, where he summarizes his former views. Riley, Leibniz' Universal Jurisprudence, pp. 152-154.

${ }^{59}$ LTS, p. 178; A I, 14, p. 57.

${ }^{60}$ LTS, p. 179; A I, 14, p. 58. 
of disinterested love from hope is only apparent, as the doctrine in fact also includes a concern for one's own good when it is understood properly. For Leibniz, this is how his own version is superior to both Fénelon's and Bossuet's accounts- his version of pure love offers immediate pleasure from our love of God. On the other hand, one can also assume that both the theological and the philosophical versions of love are helpful. Not everybody can reach the virtue and wisdom required and for them charity combined with hope is an advantageous way to conduct their lives.

Leibniz' careful argumentation reflects the central role of hope in the controversy. Fénelon held that even salvation or eternal happiness is not desirable in the indifferent state of a pure love of God and he was accused of leaving no room for the Christian virtue of hope. In his later writing from September 1697 he insisted that pure love does not hinder us from willing everything which God wills that we should will, and that indifference is wanting what God wants. ${ }^{61}$ This unconditional submitting to God's will is very different from Bossuet's practical union, where we love God and because of that we can hope for salvation. As a perceptive reader and through his contacts Leibniz must have been well aware of Fénelon's problems. Therefore one can suppose that in Sophie's eyes (and in those of the Court of Hanover in general) he wanted to distance himself from the quietist doctrine with which his previous account might have been confused and instead emphasized the significance of hope. There is no known answer by Sophie to Leibniz' letter. One wonders, however, what her motives were in asking for Leibniz' opinion on the controversy. Was she interested in the nature of love as a philosophical problem, as a theological problem or just in the controversy itself? The answer to this question is unavoidably speculative as no written evidence exists. Judging by Leibniz' approach, which was to start from the controversy and then proceed to his earlier views, it seems to me that Sophie was not necessarily interested in the concept or essence of disinterested love in itself, but more in the theological controversy which was so famous and important that she was keen to hear Leibniz' opinion about it.

One objection against this would be to point out Leibniz' indication at the beginning of the letter that Sophie had heard of his views on disinterested love before. This suggests that the letter was a continuation rather than the beginning of a discussion. ${ }^{62}$ This would perhaps also partly explain why Leibniz chose to present his views in a more theological style - utilizing the pure love controversy, he perhaps tried to introduce his doctrine in an alternative manner which would show that his doctrine can be applied to the theological

${ }^{61}$ Adams, "Pure Love," p. 87; Davis, Fénelon, pp. 84, 86-87.

${ }^{62}$ Leibniz also wrote to Sophie on disinterested love on 25 September 1708 when he commented on Louis des Ban's book L'art de connoistre les hommes (1702). Again he referred to the Codex and argued that he was writing about the topic before the pure love controversy. See LTS, p. 371. 
problem of the controversy. But as no evidence of their earlier discussions on the topic remains, this is also pure speculation. ${ }^{63}$

\section{Leibniz' Later Views on the Controversy and Disinterested Love}

Brown has argued that Leibniz' views on disinterested love stayed essentially the same after his early Elementa of $1671 .{ }^{64}$ We saw in the previous section that although Leibniz did not exactly change his mind when presenting his views to Sophie, he was ready to give them an alternative formulation which allowed for a combination of self-interested and disinterested motives. Sophie's request for Leibniz' comment on the pure love controversy was clearly a catalyst for the philosopher to rethink about his views in a theological context. The letter raises a question whether the controversy had a lasting effect on Leibniz' views. I will next provide a brief overview of Leibniz' accounts of love and comments on the pure love controversy to show that this is not the case.

Leibniz commented on the pure love controversy in exchanges with many of his numerous correspondents. ${ }^{65}$ To the learned Abbot Claude Nicaise (1623-1701) he sent comments on the controversy both in France and in England, especially celebrating Mary Astell's writings. ${ }^{66}$ In a self-congratulatory manner he wrote that it is reasonable for women to judge matters of love as it would lead them to the same conclusion he had already formed in his Codex and this would be the end of the dispute. ${ }^{67}$ Of interest is also the fact that Nicaise told Leibniz that he had sent Leibniz' views on disinterested love not only to Fénelon and Bossuet, but also to Mademoiselle de Scudéry, who refused to get involved with such an elevated topic. ${ }^{68}$

${ }^{63}$ There are varying opinions on Sophie's philosophical abilities. For a defense of Sophie's philosophical mind (he does not discuss the 1697 letter), see Lloyd Strickland, "The Philosophy of Sophie, Electress of Hanover," Hypatia 24 (2009), pp. 186-204. For criticism, see the review of LTS by Irena Backus, in Notre Dame Philosophical Reviews (29 July 2011) [accessed on 20 February 2013] http://ndpr.nd.edu/news/24775-leibniz-and-thetwo-Sophies-the-philosophical-correspondence/. Backus argues that "there is nothing within the correspondence as reproduced here to suggest that Sophie of Hanover's philosophical ability has so far been underestimated by scholars." I am inclined to think that the fact that disinterested love features several times in the correspondence between Sophie and Leibniz suggests that Sophie was interested in the topic at least to some extent.

${ }^{64}$ Brown, "Disinterested Love," p. 266.

${ }^{65}$ For a general account of Leibniz' discussion on the topic of pure love with his correspondents, see Gaston Grua, La justice humaine selon Leibniz, Paris: Presses Universitaires de France, 1956, pp. 170-180.

${ }^{66}$ Leibniz to Nicaise, 28 May1697. See also GP II, p. 580.

${ }^{67}$ GP II, pp. 569-570. Leibniz' comment is similar to the one made in the letter to Sophie: a wise person will see that his philosophical doctrine is superior to the views of the theologians.

${ }^{68}$ Nicaise to Leibniz, 27 August 1697, G, p. 119, n. 100. Madeleine de Scudéry (16071701) was a well-known French novelist and a close friend of Paul Pellison's. Leibniz first 
Leibniz gives his judgment of Fénelon's views in August 1697, saying that he thinks the Archbishop means well, but more explication is needed. Therefore he suspends his judgment on the matter and waits for further specifications. Leibniz position is made clearer in a later letter where he says that after reading some more texts he has come to see two things: the exactness of Bossuet and the innocence of Fénelon. While the former is mistaken in his doctrine, the latter suffers from good faith. While he has sympathy for Fénelon, Leibniz cannot be of exactly the same opinion as Bossuet, as his own version of disinterested love includes the idea of pleasure arising from the other's happiness. ${ }^{69} \mathrm{He}$ appears to be somewhat disappointed at Bossuet's relentless cruelty towards Fénelon in the controversy, and he approved of the papal bull of 1699 , which ended the controversy. ${ }^{70}$

Leibniz also comments on the controversy in his correspondence with André Morell (1646-1703). He argues, just as in the letter to Nicaise, that if Fénelon and Sherlock and Norris in England had been in possession of his distinct notions or definitions of disinterested love, they would have had no need for the dispute. ${ }^{71}$

The pure love controversy also features briefly in the correspondence between Leibniz and Malebranche. The latter mentions in a letter of 13 December 1698 that he had prepared a treatise on the love of God. Leibniz replies that he would be delighted to read the treatise and refers to the definitions in the Codex. In addition, he argues that divine love, which is the pleasure derived from God's perfections, is superior to all other loves and can give

sent her an introductory letter in 1697, where he mentions the pure love controversy and says that Nicaise had sent his thought to her (A I, 14, p. 748). This was followed by French verses in praise of Louis XIV (A I, 14, pp. 749-54) and letters were exchanged for two years. Nicaise probably meant by this an appendix to Leibniz' letter of 9/19 August 1697, where he comments in detail on the controversy of amour pur and gives his definition of disinterested love in full, repeating mostly the arguments in the Codex (GP II, pp. 576-580). On p. 578 Leibniz argues (as in Elementa) that in disinterested love the good follows immediately: "Mais il est visible par la notion de l'amour que nous venons de donner, comment nous cherchons en même temps nostre bien pour nous et le bien de l'objet aimé pour luy même; lorsque le bien de cet objet est immediatement, dernierement et par luy même nostre but, nostre plaisir et nostre bien, comme il arrive à l'egard de toutes les choses qu'on souhaite parce qu'elles nous plaisent par elles mêmes, et sont par consequent bonnes de soy, quand on n'auroit aucun egard aux consequences; ce sont des fins et non pas des moyens." On pp. 578-579 he argues that Fénelon's position is familiar from the writings of Averroes and Johannes Angelus.

${ }^{69}$ Leibniz to Nicaise, 23 December 1698, GP II, p. 584. Leibniz also wrote to Mme De Brinon on 15 May 1699 (G, p. 208) that pure love may be independent of our mercenary interest, but not of our good.

${ }^{70}$ Letter to Nicaise, 16 June 1699, GP II, p. 587. See also Leibniz' assessment of Fénelon's character in GP II, p. 579.

${ }^{71}$ Leibniz to Morell, 31 May 1697. In what follows, Leibniz offers his own definition of disinterested love and relates it to the promotion of general good. A I, 14, pp. 254-255. 
solid or lasting pleasure, unlike other pleasures. Leibniz adds that this should be enough to resolve the problem of the controversy and encourages Malebranche to continue the discussion. ${ }^{72}$

The topic resurfaces in many of Leibniz later writings on ethics and jurisprudence, which I have already discussed in the first section of this paper. In Nouveaux essais sur l'entendement humain (1704) II, xx, \$3-5 he gives a more theological version of his disinterested love. He first repeats his definition from the Codex and then, referring briefly to the pure love controversy, makes a distinction between concupiscent and benevolent love (situating Locke's views in the former category). Leibniz argues that benevolent love fixes our view of the pleasure of others as something which produces or rather constitutes our own pleasure. He goes on to say:

For if it did not reflect back on us somehow we could not care about it, since it is impossible (whatever they say) to disengage from a concern for one's own good. That is the way to understand "disinterested" or non-mercenary love, if we are properly to grasp its nobility and yet not succumb to fantasies about it. ${ }^{73}$

Thus he argues again on behalf of primary egoistic motivation in his conception of disinterested love. It is noteworthy that although Leibniz presents the doctrine in scholastic terms, he does not mention the virtue of hope at all. The same can be said about Essais de Theodicée (1710) and his comments on Shaftesbury's Characteristics of Men, Manners, Opinions, Times (1711), where Leibniz is again content to refer to the Codex ${ }^{74} \mathrm{He}$ mentions quietism briefly in the Preface to the Theodicy, saying that "some Christians have imagined that they could be devout without loving their neighbor." ${ }^{\text {T5 }}$

The overview above shows that Leibniz was happy to comment on the controversy with his correspondents until the Pope ended it officially in 1699. After that he was content to refer to his own role as an anticipator of the controversy and repeated his views from the Preface to the Codex iuris gentium of 1693, even within a theological context, despite his earlier attempt to provide a modified version in terms of theological virtues to Electress Sophie in 1697.

${ }^{72}$ Leibniz to Malebranche, 13 March 1699, GP I, pp. 356-358. In a letter of 17 January 1700 Leibniz reminded Malebranche that he would like to read the treatise and apparently he received it, although there are no known comments by Leibniz on the text: André Robinet, Malebranche et Leibniz: Relations personelles, Paris: Vrin, 1955, p. 330.

73 Gottfried Wilhelm Leibniz, New Essays on Human Understanding, trans. and ed. by Peter Remnant and Jonathan Bennett, Cambridge: Cambridge University Press, 1997, p. 163, A VI, 6, p. 163.

${ }^{74}$ Essais de Theodicée, Preface, GP VI, p. 27; §278, GP VI, p. 282; Appendix Remarques sur le livre de l'origine du mal, publié depuis peu en Angleterre, GP VI, p. 417; L, p. 630.

${ }^{75}$ GP VI, p. 28; Gottfried Wilhelm Leibniz, Theodicy. Essays on the Goodness of God, the Freedom of Man and the Origin of Evil, ed. with and introduction by Austin Farrer, trans. by E. M. Huggard, La Salle, Illinois: Open Court, 1996, pp. 52-53. 
This suggests that Leibniz thought that his doctrine of disinterested love in the Codex was complete and superior to any theological doctrines available, including his own in the letter to Sophie.

\section{Works Cited:}

Robert Merrihew Adams, "Pure Love," Journal of Religious Studies 8 (1980), pp. 83-99. Irena Backus, Review of Gottfried Wilhelm Leibniz, Leibniz and the Two Sophies: The Philosophical Correspondence, ed. and trans. by Lloyd Strickland, Toronto: Iter, 2011, Notre Dame Philosophical Reviews (29 July 2011) [accessed on 20 February 2013] http://ndpr.nd.edu/news/24775-leibniz-and-the-two-Sophies-the-philosophical-correspondence/.

Jacqueline Broad, Women Philosophers of the Seventeenth Century, Cambridge: Cambridge University Press, 2003.

Gregory Brown, "Leibniz' Moral Philosophy," in Brandon C. Look (ed.), Continuum Companion to Leibniz, London: Continuum, 2011, pp. 223-238.

Gregory Brown, "Disinterested Love: Understanding Leibniz' Reconciliation of Self- and Other-Regarding Motives," British Journal for the History of Philosophy 19 (2011), pp. 265-303.

James Herbert Davis, Fénelon, Boston: Twayne, 1979.

Ursula Goldenbaum, "It's Love! Leibniz's Foundation of Natural Law as the Outcome of His Struggle with Hobbes' and Spinoza's Naturalism," in Mark Kulstad, Mogens Lærke and David Snyder (eds.), The Philosophy of the Young Leibniz, Stuttgart: Steiner, 2009, pp. 189-201.

Gaston Grua, La justice humaine selon Leibniz, Paris: Presses Universitaires de France, 1956.

Nancy J. James, The Conflict over the Heresy of "Pure Love" in Seventeenth-Century France: The Tumult Over the Mysticism of Madame Guyon, Lewinston: Mellen, 2008.

Gabriel Joppin, Fénelon et la mystique du pur amour, Paris: Beauchesne, 1938.

Gottfried Wilhelm Leibniz, Die Werke I-XI, ed. by Onno Klopp, Hanover: Klindworth, 1864-84.

Gottfried Wilhelm Leibniz, Rechtsphilosophisches aus Leibnizens Ungedruckten Schriften, ed. by Georg Mollat, Leipzig: Robolsky, 1885.

Gottfried Wilhelm Leibniz, Sämtliche Schriften und Briefe, Reihe I-VIII, Berlin: Akademie, 1923-.

Gottfried Wilhelm Leibniz, Textes inédits d'après les manuscrits de la bibliothèque provinciale de Hanovre I-II, publiés et annotés par Gaston Grua, Paris: Presses Universitaires de France, 1948.

Gottfried Wilhelm Leibniz, Die philosophischen Schriften I-VII, ed. by G. I. Gerhardt, Hildesheim: Olms, 1961 (1880-90).

Gottfried Wilhelm Leibniz, Philosophical Papers and Letters, trans. and ed. with an introduction by Leroy E. Loemker, $2^{\text {nd }}$ edition, Dordrecht: Reidel, 1969.

Gottfried Wilhelm Leibniz, Political Writings, trans. and ed. with an introduction and notes by Patrick Riley, $2^{\text {nd }}$ edition, Cambridge: Cambridge University Press, 1988. 
Gottfried Wilhelm Leibniz, Theodicy. Essays on the Goodness of God, the Freedom of Man and the Origin of Evil, ed. with and introduction by Austin Farrer, trans. by E. M. Huggard, La Salle, IL: Open Court, 1996 (1985).

Gottfried Wilhelm Leibniz, New Essays on Human Understanding, trans. and ed. by Peter Remnant and Jonathan Bennett, Cambridge: Cambridge University Press, 1997 (1996).

Gottfried Wilhelm Leibniz, Leibniz and the Two Sophies: The Philosophical Correspondence, ed. and trans. by Lloyd Strickland, Toronto: Iter, 2011.

Michael Losonsky, Enlightenment and Action from Descartes to Kant: Passionate Thought, Cambridge: Cambridge University Press, 2001.

Nicolas Malebranche, Treatise on Ethics (1684), trans. with an introduction by Craig Walton, Dordrecht: Kluwer, 1992.

Pierre-Maurice Masson, Fénelon \& Mme Guyon: documents nouveaux et inédits, Paris: Hachette, 1907.

Noa Naaman Zauderer, "Rethinking Leibniz' Notions of Justice, Love and Human Motives," in Herbert Breger, Jürgen Herbst und Sven Erdner (eds.), Einheit in der Vielheit. VIII. Internationaler Leibniz-Kongress, Vorträge 2, Hannover: GottfriedWilhelm-Leibniz-Geschellschaft, 2006, pp. 671-76.

Richard Popkin, "The Religious Background of Seventeenth-Century Philosophy," in Daniel Garber \& Michael Ayers (eds.), The Cambridge History of SeventeenthCentury Philosophy, Cambridge: Cambridge University Press, 2003, pp. 393-422.

Patrick Riley, Leibniz Universal Jurisprudence: Justice as the Charity of the Wise, Cambridge, MA: Harvard University Press, 1996.

André Robinet, Malebranche et Leibniz. Relations personelles, présentées aves les textes complets des auteurs et de leur correspondants, revus, corrigés et inédits, Paris: Vrin, 1955.

Dániel Schmal, "The Problem of Conscience and Order in the Amour-Pur Debate," in Gábor Boros, Herman De Dijn, Martin Moors (eds.), The Concept of Love in Seventeenth and Eighteenth Century Philosophy, Leuven: Leuven University Press, 2008, pp. 113-124.

Tad Schmaltz, "Nicolas Malebranche," in Edward N. Zalta (ed.), The Stanford Encyclopedia of Philosophy (Winter 2009 Edition) [accessed on 23 July 2013] http:// plato.stanford.edu/archives/win2009/entries/malebranche/.

Lloyd Strickland, "The Philosophy of Sophie, Electress of Hanover," Hypatia 24 (2009), pp. 186-204.

Gerda Utermöhlen, "Die Rolle fürstlicher Frauen im Leben und Wirken von Leibniz," in Hans Poser \& Albert Heinekamp (eds.), Leibniz in Berlin, Stuttgart: Steiner, 1990, pp. 44-60.

Catherine Wilson, "Love of God and Love of Creatures: The Masham-Astell Exchange," in Gábor Boros, Herman De Dijn, Martin Moors (eds.), The Concept of Love in Seventeenth and Eighteenth Century Philosophy, Leuven: Leuven University Press, 2008, pp. 141-162. 